() C.I. Чеберячко ${ }^{1}$, О.О. Яворськка ${ }^{1}$, А.В. Яворський ${ }^{1}$, М.М. Наумов ${ }^{1}$, М.Ю. Іконніков ${ }^{1}$ ${ }^{1}$ Національний технічний університет «Дніпровська політехніка», Дніпро, Україна

\title{
РОЗРОБКА СИСТЕМИ БЕЗПЕЧНОЇ ПРАЦІ НА ГІРНИЧИХ ПІДПРИЕМСТВАХ
}

\author{
(C) S. Cheberiachko ${ }^{1}$, O. Yavorska ${ }^{1}$, A. Yavorskyi ${ }^{1}$, M. Naumov ${ }^{1}$, M. Ikonnikov ${ }^{1}$ \\ ${ }^{1}$ Dnipro University of Technology, Dnipro, Ukraine

\section{DEVELOPMENT OF SAFETY WORK SYSTEM AT MINING ENTERPRISES}

Мета. Розробка нового підходу до системи управління охороною праці на гірничих підприємствах.

Методика дослідження. В основу дослідження покладено систему безпечної праці (Safe Systems Of Work, SSOW), що представляє набір певних ретельно відібраних, виходячи з поставленої виробничої задачі, безпечних процедур, які визначаються з урахуванням компетентності працівників та характеристик обладнання.

Результати досліджень. Для зменшення професійних захворювань та травматизму запропоновано на гірничих підприємствах впровадити систему управління безпеки праці на основі ризик-орієнтованого підходу, яка складається з п'яти кроків: проаналізуй, підсумуй, передбач, підтримуй, поліпшуй. Ї̈і впровадження дозволить постійно виявляти професійні ризики та обгрунтувати шляхи їх зменшення, за рахунок удосконалення (зміни) виробничих технологій. Для реалізації кожного кроку передбачена відповідна процедура, яка дозволяє забезпечити чіткі і зрозумілі інструкцій з безпечного виконання робіт. Проведено аналіз небезпек та дана оцінка професійних ризиків на прикладі машиніста виїмкового комбайну та розроблено процедуру безпечної праці, яка представляє собою інфографіку.

Наукова новизна. Запропонована нова система безпечної праці для гірничих підприємств за ергономічним критерієм, яка передбачає зниження професійних захворювань /травмування опорно-рухового апарату, використовуючи п'ять послідовних кроків, які відповідають вимогам стандарту ISO 45001, що побудована на відомому принципі Демінга-Шухарта. Кожний крок системи підкріплений відповідними методами для виявлення професійних ризиків та рекомендацій щодо їх зменшення.

Практичне значення. Розроблені процедури (форми, інструкцій, таблиці), які дозволяють провести ідентифікацію небезпек, оцінити професійні ризики та розробити чітку зрозумілу інструкцію для безпечної праці на конкретному робочому місці.

Ключові слова: гірниче підприємство, ризик-орієнтований підхід, травматизм, система безпечної прачі, небезпечні фактори.

Постановка проблеми. Система управління безпекою праці на основі ризик-орієнтованого підходу, яка сьогодні широко впроваджується на вугільних підприємствах, на думку багатьох фахівців є не достатню результативною [1-4]. Вона продиктована реальним становищем з виробничого травматизму на вітчизняних гірничих підприємствах. Виходячи з даних Фонду соціального страхування України за 9 місяців 2019 року до підприємств з найбільшим рівнем травматизму відносяться: ПрАТ «ДТЕК Павлоградвугілля» (127 нещасних випадків), 
ПАТ «Шахтоуправління «Покровське» (29), ТОВ «ДТЕК «Добропіллявугілля» (26). Високий рівень травматизму фіксується у всьому світі, який чомусь попри всі намагання покращити ситуацію, за рахунок впровадження різноманітних систем управління безпекою працю із року в рік майже незмінний. Наприклад в США у період з 2016 по 2019 рік фіксується майже незмінна кількість нещасних випадків у вугільній галузі - близько чотирьох тисяч осіб. При цьому зі смертельним випадком за кожен рік по 27 чоловік.

Аналізуючи статистичні дані з травматизму виникають певні сумніви щодо реальної роботи направленої на зменшення професійних ризиків. Виникає думка, що небезпеки зі значним рівнем ризику занадто складно технологічно зменшити до безпечного рівня, через те, що заходи по їх зменшенню потребують значних фінансових вкладень. Ймовірно захист працівників менш важливий, чим прибуток компанії. В такому випадку здебільшого приймаються управлінські рішення і використовуються засоби індивідуального захисту, що не дозволяють фактично уникнути травм. 3 іншого боку ризикам із незначним рівнем також не приділяють належної уваги, рахуючи, що їх величина знаходиться у прийнятній зоні, що ризик заподіяти значну шкоду працівникам - мінімальний. Виходячи з розуміння окресленої проблеми, все більше небайдужих фахівців намагаються удосконалити існуючі чи запропонувати альтернативні підходи до систем управління безпекою та гігієною праці, що є сьогодні актуальною задачею.

Аналіз останніх досліджень та публікацій. Проблемам пов'язаним із забезпеченням функціонування системи управління охороною праці на основі ризик орієнтованого підходу в основу якого покладено цикл Шухарта-Демнга, присвячено досить багато робіт [5 - 9]. В них на основі аналізу травматизму, даних моніторингу небезпеки, оцінки ризику, запровадження різноманітних профілактичних заходів, показані, як сильні, так і слабкі сторони систем управління. Так, в роботі [5] встановлено, що рівень безпеки праці найбільше залежить від організаційних факторів, пов'язаних з людським фактором, які важко піддаються прогнозу. Рекомендацією було створення систем оперативного моніторингу за поведінкою працівників. Схожі висновки були зроблені і у роботі [6]. В іншій роботі [7] автори на основі дослідження взаємозв'язків між причинами нещасних випадків та організацією нормативно-правового та методичного забезпечення виробничих процесів, рекомендують чітко і ясно прописувати процедури, які необхідно виконувати працівникам. Також на неналежне виконання, через значну кількість і складність вимог охорони праці, вказується і в дослідженні, яке проведено на декількох десятках підприємств Іспанії [8]. Дослідники зазначають, що найбільше плутанини у працівників виникає з оцінкою ризиків, через відсутність єдиного підходу. В рамках дослідження $[9,10]$ зазначена необхідність забезпечення об'єктивних взаємозв'язків між процедурами ідентифікації та оцінки ризиків. Підсумовуючи останні дослідження, треба зробити висновок, що є необхідність у розробці чіткого і об'єктивного підходу до управління безпекою праці на підприємстві.

Постановка завдання. Метою даного дослідження є розробка нового підходу до системи управління охороною праці гірничих підприємств на основі вимог стандарту ISO 45001, що побудований на відомому принципі Демінга-Шухарта. 
Викладення основного матеріалу. Одним з таких підходів є розробка системи безпечної праці (Safe Systems Of Work, SSOW), що представляє набір певних ретельно відібраних, виходячи з поставленої виробничої задачі, безпечних процедур, які визначаються з урахуванням компетентності працівників та характеристик обладнання. При цьому важливим етапом $є$ ідентифікація небезпек та оцінка професійних ризиків, що проводиться не само пособі, а в комплексі при прийнятті рішення, для мінімізації негативних впливів на працівників, особливо через звичайні помилки, що і $є$ основною відмінністю запропонованої системи. Для роботодавців запровадження такого підходу не тільки допоможе запобігти нещасним випадкам, а й дозволить їм відстоювати свої права, надаючи всім зацікавленим сторонам інформацію про вжиті заходи для забезпечення безпечних практик.

Система безпечної праці складається з п'яти кроків, та званих (5П), які доволі просто реалізувати, маючи досвід роботи із системою управління безпекою праці на основі ризик-орієнтованого підходу (рис. 1):

1. проаналізуй виробниче завдання;

2. підсумуй професійні ризики;

3. передбач безпечні методи;

4. підтримуй працездатність безпечних методів;

5. поліпшуй результативність безпечної системи.

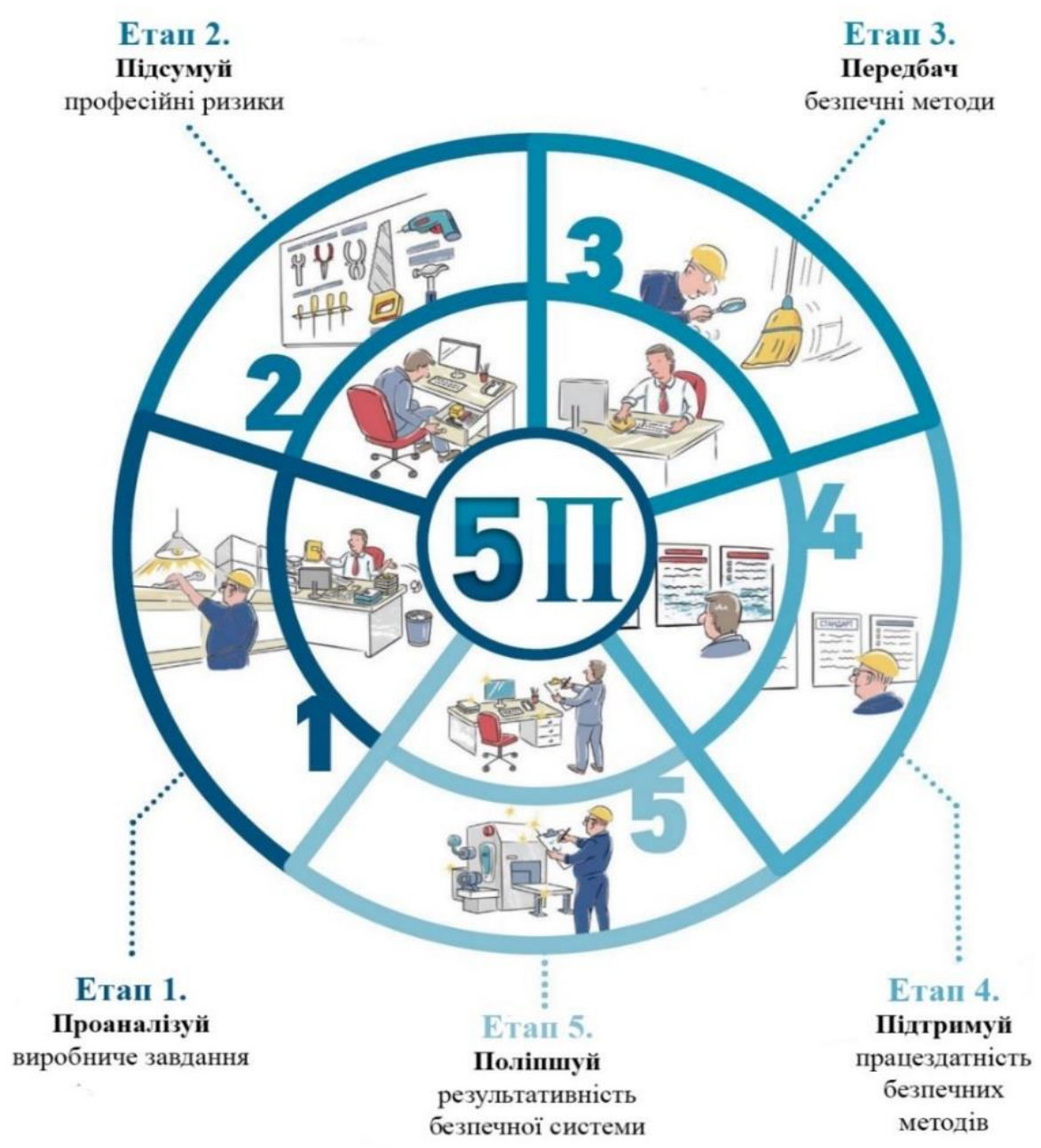

Рис.1. Система безпечної праці на основі п’яти кроків 
Перший крок- один з найважливіших від якого залежать наступні - $є$ ретельний аналіз джерел небезпек. На думку фахівців, неправильно визначені небезпеки, не дозволять забезпечити відповідний рівень безпеки на робочих місцях. Для цього потрібно переглянути інформацію, інциденти та нещасні випадки, ретельно провести огляд робочих місць із запровадженням опитування працівників, звернутись до інструкцій з використання машин і механізмів, розроблених виробниками, скористатись досвідом інших компаній і підприємств, які займаються подібним видом діяльністі. Бажано небезпеки визначати за їх класифікацією: фізичні, хімічні, біологічні, психофізіологічні та ергономічні. Можна скористатись спеціально розробленими формами, які мають безліч різних варіантів. Приклад однієї з таких форм наведено в табл. 1.

Таблиця 1

Приклад форми ідентифікації небезпек

\begin{tabular}{|l|l|l|l|l|}
\hline \multicolumn{2}{|c|}{ Ідентифікація небезпек } & Так & Ні & Коментар \\
\hline $\begin{array}{l}\text { Записи про } \\
\text { травми }\end{array}$ & $\begin{array}{l}\text { Ретельно перевірити форми актів Н-1 про } \\
\text { причини, травми або нещасні випадки }\end{array}$ & & \\
\hline $\begin{array}{l}\text { Опитування } \\
\text { співробітників }\end{array}$ & $\begin{array}{l}\text { Провести опитування співробітників на виявлення } \\
\text { наявних небезпек, які можуть призвести до травми } \\
\text { чи небезпечних ситуацій, інцидентів }\end{array}$ & & \\
\hline $\begin{array}{l}\text { Фізичні, } \\
\text { ергономічні } \\
\text { небезпеки }\end{array}$ & $\begin{array}{l}\text { Наявність фізичних навантажень, переміщення } \\
\text { вантажу, механізмів, що обертаються чи } \\
\text { рухаются, незручнихекстремальних поз, } \\
\text { захватів, повторювальних рухів, постійного } \\
\text { нахилу тулуба та інше. Можливість падіння, } \\
\text { ковзання, нерівна поверхня, пандуси, сходи інше. }\end{array}$ & & & \\
\hline $\begin{array}{l}\text { Гігієнічні } \\
\text { небезпеки }\end{array}$ & $\begin{array}{l}\text { Вплив екстремальних температур, недостатнього } \\
\text { освітлення, підвищеного шуму, запиленості, } \\
\text { вібрації, електромагнітних випромінювань, інше. }\end{array}$ & & & \\
\hline $\begin{array}{l}\text { Психо- } \\
\text { фізіологічні } \\
\text { небезпеки }\end{array}$ & $\begin{array}{l}\text { Тривалість спостереження, частота сигналів, } \\
\text { кількість об'єктів спостереження, напруженість } \\
\text { очей, одноманітність роботи, наднормова робота, } \\
\text { режим праці, темп/ритм роботи, зміна завдань, } \\
\text { моторика дрібних рухів тощо }\end{array}$ & & & \\
\end{tabular}

Другий крок полягає у встановлені небезпек і величини професійних ризиків від дії небезпечних факторів, які можуть вплинути на робітників при виконання виробничих завдань, включно $з$ психологічними аспектами впливу на працівників.

Оцінка ризиків - це фундаментальний процес, що є основою успішного управління безпекою праці. Вона представляє собою письмово процедуру, яка допомагає розробити систему безпечної праці.

Оцінку ризиків проводять у наступній послідовності (табл. 2):

1. визначте завдання або робочу операцію та опишіть небезпеки (колонка 1);

2. визначте та запишіть відповідні наслідки дії небезпеки на людину (колонка 2);

3. визначте осіб, які знаходяться в зоні ризику (колонка 3); 
4. визначте існуючі заходи контролю ризику для кожного випадку (колонка 4);

5. візьміть до уваги серйозність (колонка 5) і ймовірність (колонка 6) небезпеки, а також за допомогою індикатора рівня ризику, визначте рейтинг ризику $\mathrm{i}$ запишіть (колонка 7);

6. якщо для контролю або зменшення ризику потрібні додаткові елементи керування, це має бути записано (колонка 8).

Таблиця 2

Шаблон оцінки ризиків

\begin{tabular}{|c|c|c|c|c|c|c|c|}
\hline 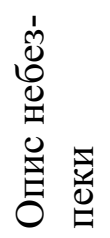 & 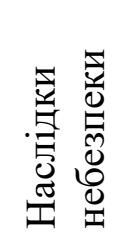 & $\begin{array}{l}\frac{\sigma}{0} \\
0 \\
0 \\
0 \\
0 \\
0\end{array}$ & 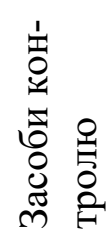 & 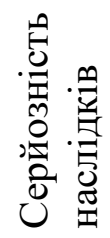 & 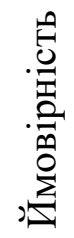 & 总 & 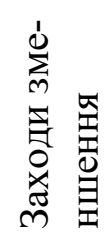 \\
\hline 1 & 2 & 3 & 4 & 5 & 6 & 7 & 8 \\
\hline
\end{tabular}

Шкала для оцінки ризику і його інтерпретація наведені в табл. $(3,4)$

Таблиця 3

Шкала для оцінки ризику

\begin{tabular}{|l|c|c|c|c|c|c|}
\hline \multicolumn{1}{|c|}{ Ймовірність } & $\begin{array}{c}\text { Майже } \\
\text { неможливо }\end{array}$ & $\begin{array}{c}\text { Мало- } \\
\text { ймовірно }\end{array}$ & Можливо & Ймовірно & $\begin{array}{c}\text { Безпе- } \\
\text { речно }\end{array}$ \\
\cline { 1 - 7 } Тяжкості & 1 & 2 & 3 & 4 & 5 \\
\hline $\begin{array}{l}\text { Тривіальна травма } \\
\text { або біль від удару }\end{array}$ & 1 & 1 & 2 & 3 & 4 & 5 \\
\hline $\begin{array}{l}\text { Незначні травми або } \\
\text { вивихи }\end{array}$ & 2 & 2 & 4 & 6 & 8 & 10 \\
\hline $\begin{array}{l}\text { Травма, що вимагає } \\
\text { медичного лікування }\end{array}$ & 3 & 3 & 6 & 9 & 12 & 20 \\
\hline $\begin{array}{l}\text { Травма викликає } \\
\text { тривале лікування і } \\
\text { втрату певної функції }\end{array}$ & 4 & 4 & 8 & 12 & 16 & 25 \\
\hline $\begin{array}{l}\text { Травми призводять } \\
\text { до інвалідності чи } \\
\text { смерті }\end{array}$ & 5 & 5 & 10 & 15 & 20 & 2 \\
\hline
\end{tabular}


Опис діаграми

\begin{tabular}{|l|l|}
\hline \multicolumn{1}{|c|}{ Ризик } & \multicolumn{1}{|c|}{ Дії } \\
\hline Високий $15-25$ & $\begin{array}{l}\text { Завдання не може починатися або бути негайно зупинене. Інфо- } \\
\text { рмувати вище керівництво }\end{array}$ \\
\hline Помірний 6-14 & $\begin{array}{l}\text { Завдання не може починатися або бути негайно зупинене. Про- } \\
\text { консультуйтеся з керівництвом, щоб отримати дозвіл }\end{array}$ \\
\hline Низький 1-5 & $\begin{array}{l}\text { Завдання може виконуватись або продовжуватися із обов’язко- } \\
\text { вим інформуванням про безпечні методи роботи. Обов’язковий } \\
\text { контроль за роботою. }\end{array}$ \\
\hline
\end{tabular}

Третій крок направлений на оцінку безпечності робіт на виробництві, який базується на прогнозі можливих інцидентів. Даний крок дозволить компаніям передбачити і попередити нещасні випадки. Скористаємось рекомендаціями інституту з охорони праці США, які говорять, що зменшення інцидентів можливе за рахунок запровадження постійних перевірок визначних показників, які дозволяють зібрати статистичні дані для побудови моделей з прогнозу розвитку ситуації.

Четвертий крок - розробка безпечних методів роботи у випадках існування навіть незначного рівня ризику, що є однією з відмінностей даного підходу від ризик-орієнтованого.

В системі безпечної праці не існує чіткої вимоги до процедур доведення необхідної інформації до працівників. Це може бути і усно, і письмово, і офіційним дозволом. Однак вона вимагає чітко дотримуватись форми надання інформації. Обов'язковою $є$ процедура підготовки до роботи (необхідні дозволи, розпорядження, засоби захисту), планування послідовності виконання роботи, безпечні способи роботи, можливі аварійні ситуації та дії під час їх виникнення, особливості при закінченні роботи (демонтаж, утилізація, вимкнення і т.д.).

Кожна робота вимагає своєрідного підходу, який враховує їі специфіку, рівень ризику, фаховість працівників, умови праці та інше. Наприклад, для робіт 3 невисоким ризиком, можна навести набір певних правил, виконання яких гарантує безпеку. На відміну для робіт з високим ризиком, необхідно не тільки ретельно виписати інструкції, а й вимоги до виконавців, їх навчання і перевірку компетентності. Рекомендується використовувати чек-листи, де описаний кожен крок (табл. 5). 
Форма системи безпечної праці

\begin{tabular}{|c|c|}
\hline Місце роботи & Місце де виконується робота \\
\hline Відповідальна особа & ПІБ \\
\hline Дата створення & Дата створення \\
\hline Інспектор & Хто здійснював перевірку \\
\hline Опис роботи & Опишіть, яку роботу буде зроблено \\
\hline Завдання & Що потрібно зробити \\
\hline Методи роботи & Як потрібно зробити \\
\hline Навчання & Що пробує особливої уваги \\
\hline Ідентифікація небезпек & Опишіть небезпеки та оцініть ризики Додаток А \\
\hline Оцінка ризиків & Додаток Б \\
\hline Планування роботи & Основна мета і кінцевий результат проекту \\
\hline Підготовчі роботи & Що потрібно зробити перед початком роботи \\
\hline $\begin{array}{l}\text { Інструменти та } \\
\text { обладнання }\end{array}$ & Опишіть необхідне обладнання \\
\hline Потрібно ЗІЗ & Який персональний захист потрібен для завдання \\
\hline Процедури & Безпечної робочої процедури Додаток В \\
\hline \multirow[t]{2}{*}{ Аварійні заходи } & Опишіть дії під час аварійних ситуацій \\
\hline & $\begin{array}{l}\text { Вкажіть необхідність утилізації та видалення відходів, } \\
\text { прибирання робочого місця }\end{array}$ \\
\hline
\end{tabular}

П'ятий крок направлений на забезпечення регулярного моніторингу працездатністю системи, підготовку працівників, виконання ними інструкцій і правил. На даному етапі важливо забезпечити зворотний зв'язок для отримання відповідей стосовно результативності системи, виконанням процедур, виявлення проблем і розробки змін для покращення роботи. Необхідно організувати «зупинку» роботи при встановлені небезпечних станів обладнання чи поведінки людей. Важливо забезпечити моніторинг за виконанням процедур, щоб переконатись у працездатності системи, виконанні процедур працівниками, а при необхідності швидко зробити корективи.

Результати дослідження. Важливим етапом роботи - $є$ встановлення потенційних потерпілих і наслідків для їх здоров'я. Така інформація дасть можливість розробити заходи щодо запобігання небажаних ризикованих ситуацій. Йдеться про визначення груп людей, а не кожного окремого робітника, який знаходиться в зоні підвищеного ризику (наприклад, «працівники складу» або «ті, хто проходить повз»). Для кожного випадку необхідно визначити можливий характер травми або захворювання.

Для заповнення таблиці 1 потрібно провести певні підготовчі кроки, які полягають у визначенні технологічних процесів та небезпек, які їм притаманні, засобів контролю. На думку фахівців - це один із найважливіших етапів. Для прикладу, візьмемо небезпеки характерні для роботи машиніста виїмкового комбайну на вугільній шахті (табл. 6). 
Таблиця 6 Приклад визначення вибіркових небезпек і виробничих ризиків на дільниці 3 видобутку вугілля

\begin{tabular}{|c|c|c|c|c|c|c|c|}
\hline Процес & Небезпеки & $\begin{array}{c}\text { Вид } \\
\text { небезпеки }\end{array}$ & $\begin{array}{c}\text { Наслідки } \\
\text { небезпеки }\end{array}$ & $\begin{array}{c}\text { Серйозність } \\
\text { наслідків }\end{array}$ & $\begin{array}{l}\text { Ймовір- } \\
\text { ність }\end{array}$ & Ризик & $\begin{array}{c}\text { Заходи } \\
\text { зменшення }\end{array}$ \\
\hline \multirow{6}{*}{ 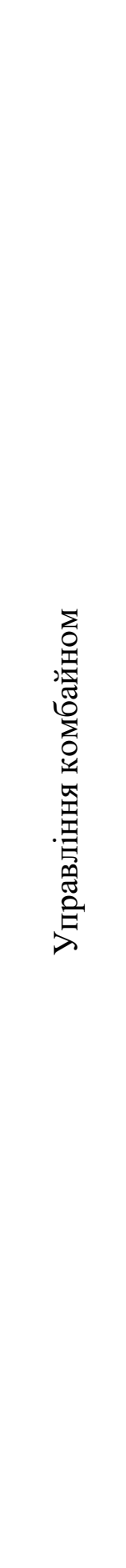 } & 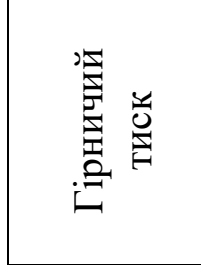 & 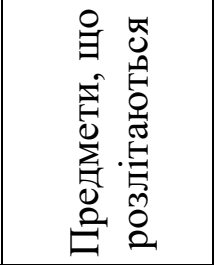 & \multirow{3}{*}{ 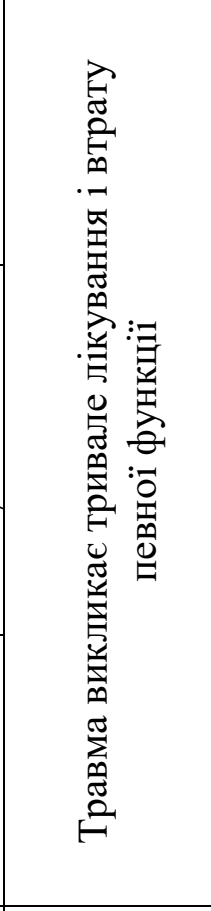 } & 4 & 4 & 16 & $\begin{array}{c}\text { Виконання } \\
\text { вимог ПБ, } \\
\text { вимог паспорту } \\
\text { виїмкової } \\
\text { дільниці }\end{array}$ \\
\hline & 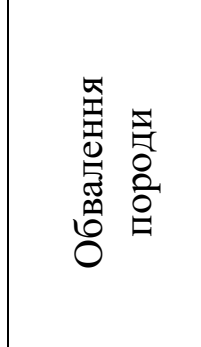 & 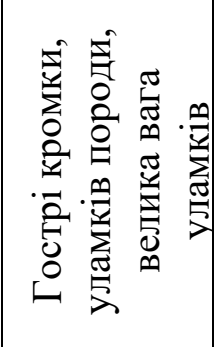 & & 4 & 4 & 16 & $\begin{array}{c}\text { Виконання } \\
\text { вимог ПБ, } \\
\text { вимог паспорту } \\
\text { виїмкової } \\
\text { дільниці. } \\
\text { Працююче } \\
\text { кріплення }\end{array}$ \\
\hline & 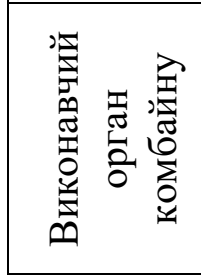 & 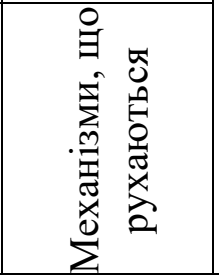 & & 4 & 4 & 16 & $\begin{array}{c}\text { Виконання } \\
\text { вимог ПБ, } \\
\text { вимог паспорту } \\
\text { виїмкової } \\
\text { дільниці. }\end{array}$ \\
\hline & 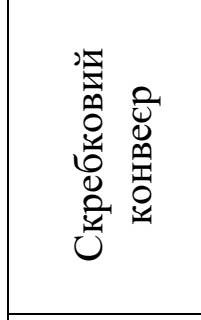 & 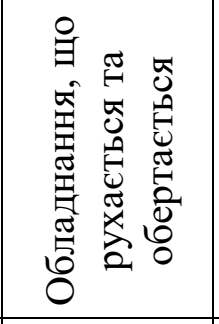 & & 4 & 4 & 16 & $\begin{array}{c}\text { Виконання } \\
\text { вимог ПБ, } \\
\text { вимог паспорту } \\
\text { виїмкової } \\
\text { дільниці. } \\
\text { Інструкції з ОП }\end{array}$ \\
\hline & \multirow{2}{*}{ 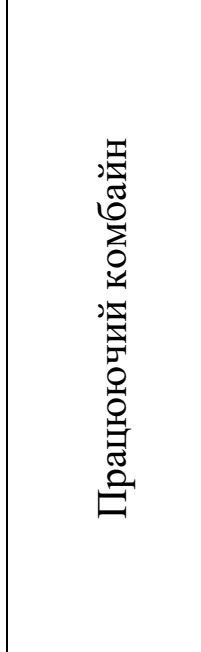 } & 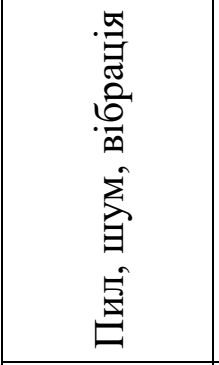 & 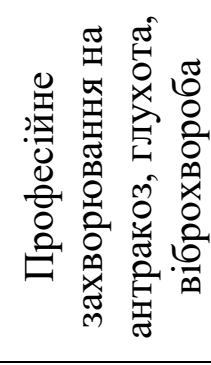 & 5 & 5 & 25 & $\begin{array}{c}\text { Засоби } \\
\text { пилеподавлення } \\
\text { Вентиляція } \\
\text { виробок, ЗІЗОД }\end{array}$ \\
\hline & & 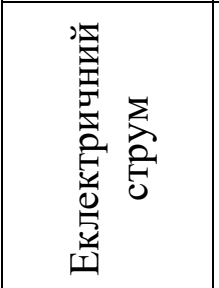 & 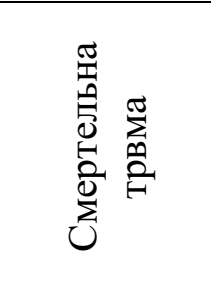 & 5 & 4 & 20 & $\begin{array}{c}\text { Виконання } \\
\text { вимог ПБ, } \\
\text { вимог паспорту } \\
\text { виїмкової } \\
\text { дільниці. } \\
\text { Інструкції з ОП }\end{array}$ \\
\hline
\end{tabular}


Проаналізувавши небезпеки і величини виробничих ризиків, необхідно встановити ті технологічні процеси, де не вдалось за допомогою засобів колективного захисту, зменшити ймовірність травмування (табл. 7).

Таблиця 7

Фрагмент з аналізу досягнутого рівня безпеки

\begin{tabular}{|c|c|c|c|c|}
\hline \multirow[t]{2}{*}{ Небезпека } & \multirow{2}{*}{$\begin{array}{c}\text { Величина } \\
\text { ризику }\end{array}$} & \multirow[t]{2}{*}{ Контроль за ризиком } & \multicolumn{2}{|c|}{$\begin{array}{c}\text { Безпечний } \\
\text { рівень досягнуто }\end{array}$} \\
\hline & & & Так & $\mathrm{Hi}$ \\
\hline $\begin{array}{l}\text { Предмети, що } \\
\text { розлітаються, } \\
\text { обвалюються }\end{array}$ & 16 & $\begin{array}{lr}\text { Забезпечення } & \text { відповідної } \\
\text { несучої } & \text { спроможності, } \\
\begin{array}{l}\text { виконання } \\
\text { кріплення лави }\end{array} & \text { паспорту }\end{array}$ & Так & \\
\hline $\begin{array}{l}\text { Гострі кромки, } \\
\text { уламків } \\
\text { породи, велика } \\
\text { вага уламків }\end{array}$ & 16 & $\begin{array}{l}\text { Своєчасна } \\
\text { запобіжного, тимчасового } \\
\text { i постійноїго кріплення } \\
\text { згідно з паспортом }\end{array}$ & Так & \\
\hline $\begin{array}{l}\text { Обладнання, } \\
\text { що рухається }\end{array}$ & 16 & $\begin{array}{l}\text { Інструментальний } \\
\text { контроль, системи } \\
\text { відключення, контроль за } \\
\text { тиском в системі }\end{array}$ & ні & \\
\hline $\begin{array}{l}\text { Обладнання, } \\
\text { що рухається } \\
\text { та обертається }\end{array}$ & 16 & $\begin{array}{lr}\text { Апарат } & \text { контролю } \\
\text { роботою } & \text { скребкового } \\
\text { конвеєру } & \\
\end{array}$ & так & \\
\hline Пил & 25 & $\begin{array}{lr}\text { Контроль } & \text { за } \\
\text { концентрацією пилу } \\
\text { повітрі робочої зони; за } \\
\text { станом } \\
\text { для пилоподавлення } \\
\end{array}$ & Hi & \\
\hline $\begin{array}{l}\text { Електричний } \\
\text { струм }\end{array}$ & 20 & \begin{tabular}{lr} 
Постійний & \multicolumn{2}{c}{ догляд } \\
відповідними & особами за \\
електрообладнанням & \\
дільниці; & оснащенням \\
засобами & електробезпеки \\
(захисне & заземлення, \\
автоматичне & \\
відключення)
\end{tabular} & так & \\
\hline
\end{tabular}

Аналіз даних в таблиці 7 говорить про недостатній рівень контролю за деякими небезпеками. Рівень виробничого ризику за ними великий і не вдалось досягнути існуючими засобами контролю прийнятності цих ризиків. Тому виникає необхідність розробки та впровадження відповідних працеохороних заходів, які б дозволили зменшити величину ризику до прийнятного рівня, що чітко описано в (табл. 8). 
Таблиця 8

Процедура безпечної роботи для машиніста виїмкового комбайну

\begin{tabular}{|c|c|}
\hline $\begin{array}{l}\text { Приміщення та } \\
\text { місце роботи }\end{array}$ & Видобувна дільниця \\
\hline \multicolumn{2}{|l|}{\begin{tabular}{l|} 
Робочий \\
/керівник \\
адміністратор
\end{tabular}} \\
\hline \multicolumn{2}{|l|}{ Дата створення } \\
\hline \multicolumn{2}{|l|}{ Інспектор } \\
\hline Опис роботи & $\begin{array}{l}\text { Виїмка вугілля проводиться комбайном за човниковою схемою. При } \\
\text { русі комбайна до збірного штреку проводиться видобуток вугілля, у } \\
\text { зворотному напрямі також. } \\
\text { На початку зміни машиніст комбайну проводять підготовку його до } \\
\text { роботи відповідно до Інструкції } 3 \text { експлуатації. При ввімкненні } \\
\text { комбайну обов’язково подається звуковий сигнал. В процесі роботи } \\
\text { машиніст комбайну постійно знаходиться за пультом керування } \\
\text { забезпечує його правильну і безпечну роботу. }\end{array}$ \\
\hline Завдання & Управління видобувним комбайном \\
\hline \multirow{5}{*}{$\begin{array}{l}\text { Метод, який } \\
\text { слід } \\
\text { застосовувати, } \\
\text { та заходи } \\
\text { безпеки }\end{array}$} & $\begin{array}{l}\text { Забороняється знаходитись в зоні видобутку вугілля під час роботи } \\
\text { комбайну чи виконувати будь-які роботи. Забороняється прохід людей } \\
\text { по лаві в зоні переміщення секцій і біля комбайну при його роботі. }\end{array}$ \\
\hline & $\begin{array}{l}\text { Робота комбайну не допускається при наявності перепадів опорних } \\
\text { поверхонь, рештаків, навісного обладнання чи зсуву їх один від одного } \\
\text { більше } 8 \text { мм, а також порушення прямолінійних направляючих }\end{array}$ \\
\hline & $\begin{array}{l}\text { При сходженні комбайна } 3 \text { направляючих конвеєра, або опорних } \\
\text { поверхонь навісного обладнання, заклинювання, комбайн негайно } \\
\text { зупиняється, робочі ланки по гучномовному зв'язку попереджаютья } \\
\text { про причину зупинки. Роботи по виїмці вугілля комбайном, } \\
\text { пересування секцій кріплення, пересуванні конвеєра припиняються, } \\
\text { вживаються заходи щодо усунення несправності. Робота комбайну } \\
\text { відновлюється тільки після усунення небезпечної ситуації з дозволу } \\
\text { відповідальної особи. }\end{array}$ \\
\hline & $\begin{array}{l}\text { Прохід працівників на зустріч руху комбайну дозволяється тільки між } \\
\text { первим і другим рядами стійок кріплення }\end{array}$ \\
\hline & $\begin{array}{l}\text { Після відпрацювання лави, дільницю необхідно своєчасно ізолювати } \\
\text { перемичками }\end{array}$ \\
\hline Навчання & $\begin{array}{l}\text { Інструктаж з безпеки праці за стандартною методикою та інструкціями } \\
3 \text { використання машин і механізмів. } \\
\text { Поточне навчання } 3 \text { безпечної експлуатації виїмкового комплексу } \\
\text { забезпечується при видачі нарядів для виробництва робіт і має } \\
\text { включати «інструкцію з безпеки» }\end{array}$ \\
\hline $\begin{array}{l}\text { Ідентифікація } \\
\text { небезпек }\end{array}$ & Ідентифікація небезпек наведена у таблиці 6 \\
\hline Оцінка ризиків & Оцінка ризиків наведена у таблиці 7 \\
\hline $\begin{array}{l}\text { Установки та } \\
\text { обладнання, } \\
\text { яке буде } \\
\text { використовува- } \\
\text { тися }\end{array}$ & $\begin{array}{l}\text { Пристрої для уникнення самовільного ковзання, засобами для } \\
\text { подачі/підбирання кабелів, шлангів, форсунки для пилоподавлення, } \\
\text { система блокування для зупинки роботи при непрацюючих засобах } \\
\text { знепилення, метанреле для автоматичного відключення напруги, } \\
\text { гідравлічні рукава. }\end{array}$ \\
\hline
\end{tabular}


Продовження таблиці 8 Процедура безпечної роботи для машиніста виїмкового комбайну

\begin{tabular}{|c|c|}
\hline \multirow[t]{3}{*}{$\begin{array}{l}\text { Заходи } \\
\text { безпеки }\end{array}$} & $\begin{array}{l}\text { Колективними засобами захисту на дільниці є засоби пиловибухозахисту, } \\
\text { водяні заслони, комплекс заходів із знепилення, засоби пожежогасіння: } \\
\text { ящик } 3 \text { піском, пожежний трубопровід, вогнегасники, УВПК на } \\
\text { стрічкових конвеєрах; засоби газового захисту: апаратура автоматичного } \\
\text { контролю метану; переносні газоаналізатори, пиломіри. }\end{array}$ \\
\hline & $\begin{array}{l}\text { Засоби індивідуального захисту органів дихання, слуху, опорно-рухового } \\
\text { апарату (наколінники, налокітники), спецодяг, захисні каски, окуляри. }\end{array}$ \\
\hline & Небезпечні дії наведені у додатку А \\
\hline \multirow[t]{3}{*}{$\begin{array}{l}\text { Аварійні } \\
\text { заходи }\end{array}$} & $\begin{array}{l}\text { У випадку аварійної ситуації виконується оповіщення працівників через } \\
\text { гучномовці. При отримані такого сигналу необхідно діяти у відповідності } \\
3 \text { ПБ працівників шахти в аварійних ситуаціях і Планом ліквідації аварії. }\end{array}$ \\
\hline & $\begin{array}{lcccc}\text { Випадку появи шкідливих газів, виникнення пожежі негайно } \\
\text { використовується шахтний саморятівник }\end{array}$ \\
\hline & $\begin{array}{l}\text { Перша допомога: Використовуються засоби } 3 \text { медичної аптечки при } \\
\text { наданні долікарської допомоги на робочому місці }\end{array}$ \\
\hline $\begin{array}{l}\text { Санітарно- } \\
\text { побутове } \\
\text { забезпечення }\end{array}$ & \\
\hline
\end{tabular}

Приклад піктограми для машиніста комбайну

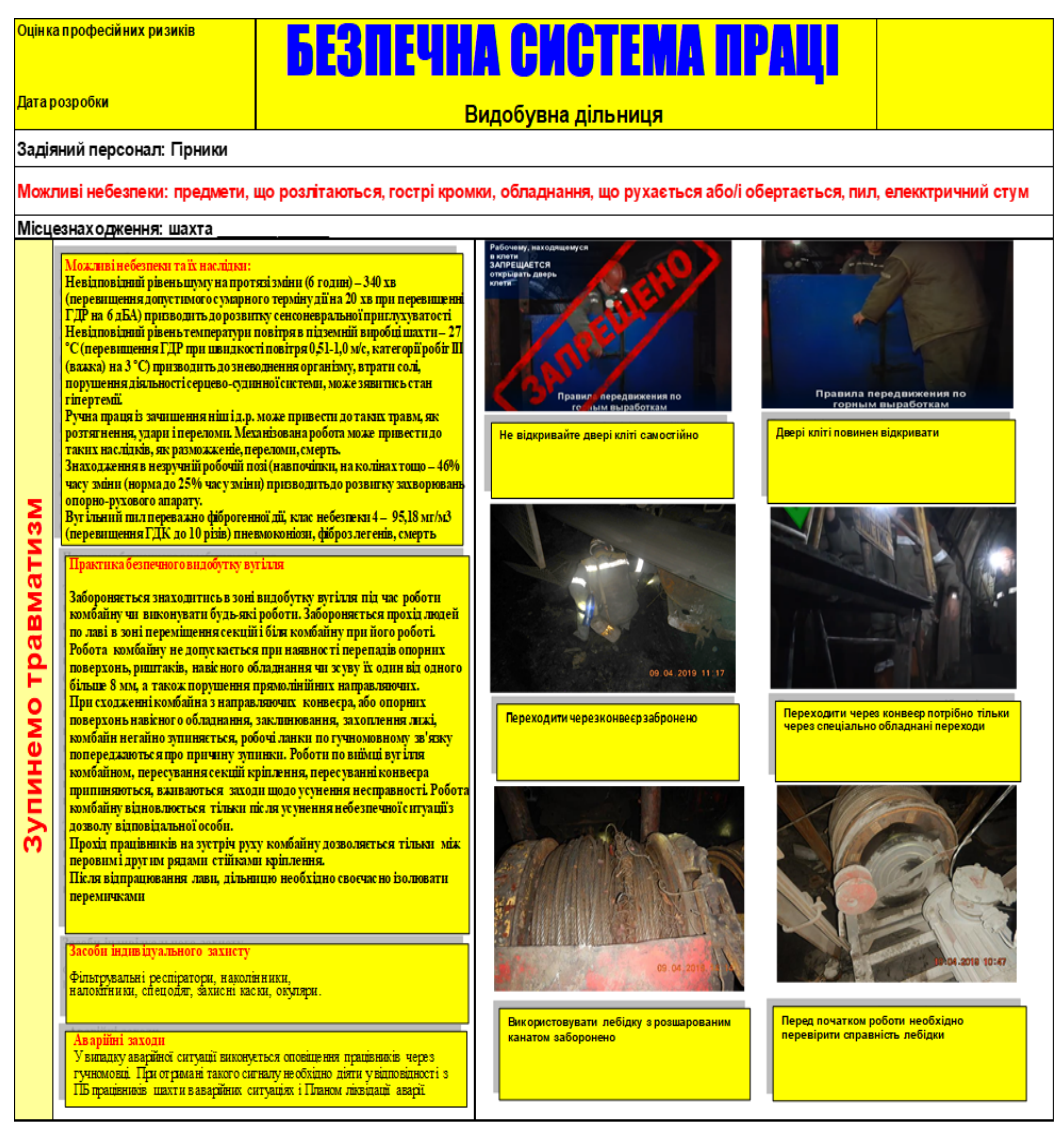


Обговорення. В цілому результати моделювання системи безпечної праці, дозволяють адекватно обгрунтувати заходи безпеки та розробити інструкції, які дозволять зменшити захворювання і травматизм. Система управління безпекою праці на основі ризик-орієнтованого підходу, яка сьогодні широко впроваджується на вітчизняних гірничих підприємствах, на думку багатьох фахівців не досить результативна $[11,12]$, що підкріплено реальним становищем з виробничого травматизму на підприємствах та спонукає до певних сумнівів щодо охоплення даним підходом всіх аспектів виробничої діяльності підприємства. Довести всі ризики до прийнятного рівня дуже складно і потребує великих коштів, а інколи це технологічно не можливо. В такому випадку здебільшого приймаються управлінські рішення і використовуються засоби індивідуального захисту, що не дозволяє фактично уникнути травм.

3 іншого боку професійним ризикам із незначним рівнем також не приділяють належної уваги, рахуючи, що їх величина знаходиться у прийнятній зоні, що не може причинити значної шкоди працівникам. Виходячи з розуміння окресленої проблеми, все більше небайдужих фахівців намагаються удосконалити існуючі чи запропонувати альтернативні підходи до систем управління безпекою та гігієною праці. Тому запропонована система підвищення безпеки праці з урахуванням різнобічних критеріїв в тому числі і ергономічних, дозволить не тільки

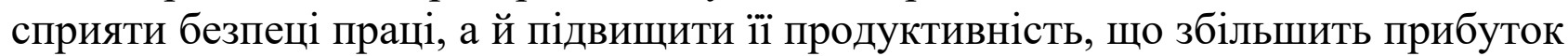
компанії, а та окупить витрати на охорону праці.

Однак у даного підходу є певні недоліки, зокрема критики стверджують, що впровадження даної стратегії може за певних обставин призвести до зростання бюрократичної системи з управління безпекою і гігієною праці, що пов'язане зі значною кількістю різного роду формальних процедур, необхідністю впровадження жорсткого контролю за поведінкою працівників, збільшення навчального навантаження, для якого потрібно знаходити час поза основним - робочим.

Також у разі формалізації підходів буде сформовано культуру скептицизму, цинізму, страху відкритості через побоювання зменшення виплат чи отримання покарання. При чому вказується на можливість заниження показників травматизму, приховування порушень для досягнення кращих показників. Вважається, що для реалізації подібної системи, потрібно впровадження дуже жорсткого контролю за виконанням бюрократичних процедур, поведінкою робітників та можливим шахрайством

Висновки. Запропоновано п’ять кроків (5П) для системи управління безпекою праці гірничого підприємства на основі ризик-орієнтованого підходу: проаналізуй виробниче завдання; підсумуй професійні ризики; передбач безпечні методи; підтримуй працездатність безпечних методів; поліпшуй результативність безпечної системи. Розроблено карту системи безпечної праці для машиніста виїмкового комбайну. Впровадження даної системи дозволить не просто говорити про безпеку праці, виходячи з ризик-орієнтованого підходу, але активно впроваджувати практики, розширюючи можливості за рахунок розробки безпечних процедур про результативність яких завжди можна дізнатись із зворотного зв'язку з працівниками шахт. 
1. ISO 45001 - All you need to know (2020). Retrieved from: https://www.iso.org/ru/news/ref2271.html

2. ISO 31000 Risk management (2020). Retrieved from: https://www.iso.org/iso-31000-risk-management.html

3. Karkoszka, T. (2017), Operational monitoring in the technological process in the aspect of occupational risk. Procedia Manufacturing, 13, 1463-1469.

https://doi.org/10.1016/j.promfg.2017.09.192

4. Cheberiachko, S.I., Yavorskyi, A.V., Yavorska, O.O., Tykhonenko, V. V. (2018): Evaluating the risks of occupational respiratory diseases of coal mine workers. Naukovyi Visnyk Natsionalnoho Hirnychoho Universytetu; (6), 104-111.

https://doi.org/10.29202/nvngu/2018/13

5. Philip P.Purpura (2019). Safety in the Workplace. Security and Loss Prevention (Seventh Edition), 435-455.

https://doi.org/10.1016/B978-0-12-811795-8.00014-X

6. Anaya-Aguilar, R., Suárez-Cebador, M., Rubio-Romero, J. C., \& Galindo-Reyes, F. (2018). Delphi assessment of occupational hazards in the wineries of Andalusia, in southern Spain. Journal of Cleaner Production, 196, 297-303.

https://doi.org/10.1016/j.jclepro.2018.06.008

7. Cąliş, S., \& Buÿükakinci, B. Y. (2019). Occupational Health and Safety Management Systems Applications and A System Planning Model. Procedia Computer Science, 158, 1058-1066. https://doi.org/10.1016/j.procs.2019.09.147

8. Heras-Saizarbitoria, I., Boiral, O., Arana, G., \& Allur, E. (2019). OHSAS 18001 certification and work accidents: Shedding Light on the connection. Journal of Safety Research, 68, 33-40. https://doi.org/10.1016/j.jsr.2018.11.003

9. Kalkis, H. (2014). Business Ergonomics Management. Gutenbergs Druka.

10. Neumann, W.P. (2007). Inventory of Human Factors Tools and Methods. Ontario Workplace Safety and Insurance Board.

\begin{abstract}
АННОТАЦИЯ
Цель. Разработка нового подхода к системе управления охраной труда на горных предприятиях.

Методика исследования. В основу исследования положена система безопасного труда (Safe Systems Of Work, SSOW), представляющая набор определенных тщательно отобранных, исходя из поставленной производственной задачи, безопасных процедур, которые определяются с учетом компетентности работников и характеристик оборудования.

Результаты исследований. Для уменьшения профессиональных заболеваний и травматизма предложено на горных предприятиях внедрить систему управления безопасности труда на основе риск-ориентированного подхода, которая состоит из пяти шагов: проанализируй, подытожь, предусмотри, поддерживай, улучшай. Ее внедрение позволит постоянно выявлять профессиональные риски и обосновывать пути их уменьшения, за счет усовершенствования (смены) производственных технологий. Для реализации каждого шага предусмотрена соответствующая процедура, которая позволяет обеспечить четкие и понятные инструкции по безопасному выполнению работ. Проведен анализ опасностей и дана оценка профессиональных рисков на примере машиниста выемочного комбайна и разработана процедура безопасного труда, которая представляет собой инфографику.
\end{abstract}


Научная новизна. Предложена новая система безопасного труда для горных предприятий по эргономическому критерию, которая предусматривает снижение профессиональных заболеваний /травмирования опорно-двигательного аппарата, используя пять последовательных шагов, которые отвечающие требованиям стандарта ISO 45001, построенная на известном принципе Деминга-Шухарта. Каждый шаг системы подкреплен соответствующими методами для выявления профессиональных рисков и рекомендаций по их уменьшению.

Практическое значение. Разработанные процедуры (формы, инструкции, таблицы), которые позволяют провести идентификацию опасностей, оценить профессиональные риски и разработать четкую понятную инструкцию для безопасного труда на конкретном рабочем месте.

Ключевые слова: горное предприятие, риск-ориентированный подход, травматизм, система безопасного труда, опасные факторы.

\begin{abstract}
Objective is to develop innovative approach to the system of labour safety control at mining enterprises.
\end{abstract}

Research methodology. The research is based on the Safe Systems Of Work, SSOW, being a set of certain thoroughly selected (relying on the formulated industrial task) safe procedures, which are defined taking into consideration the staff competence and equipment characteristics.

Findings. To reduce occupational diseases and injuries, it is proposed for enterprises to provide a system of safe work control based on the risk-oriented approach. The system consists of five steps: analyze, summarize, forecast, support, and improve. Its implementation will make it possible to monitor occupational risks and substantiate the ways of their decrease by improving (changing) the production technologies. Implementation of each step means corresponding procedure, which helps provide clear instructions for safe performance of operations. Dangers and occupational risks have been analyzed in terms of a coal shearer operator. A procedure of safe work has been developed; the procedure is represented in the infographic form.

Originality. The proposed innovative safe work system for mining enterprises is based on the ergonomic criteria, which means decrease in occupational diseases/injuries of the musculoskeletal system. The five steps of the system correspond to the well-known principle of Deming-Shewhart. Each step is supported by the corresponding methods to detect occupational risks and to elaborate recommendations as for their decrease.

Practical implications. The procedures (forms, instructions, tables) have been developed making it possible to identify dangers, to evaluate occupational risks, and to develop clear instructions for safe work at a specific workplace.

Keywords: mining enterprise, risk-oriented approach, injuries, safe work system, dangerous factors. 